\title{
Financial Governance After the Great Recession: What Changed and What Didn't?
}

Jan Kregel Levy Economics Institute of Bard College

\begin{abstract}
Finance in general, and banking in particular, are probably the only areas of the economic system where there is widespread agreement on the necessity of formal governance. Most governments reserve for themselves the right to issue debt in the form of coins and currency; in addition private providers of means of payment have failed so frequently to provide a safe and secure means of payment, with disastrous consequences for the operation of the real economy that governments have sought to regulate financial to prevent financial crisis. However, in an open global economy the regulations of national governments have little impact on the operation of global financial markets which are regulated by the governments of developed countries. Thus the regulations determined in developed country markets, in particular the US are of crucial importance to the governance of finance in developing countries. This paper considers the main innovations of developed country governance in the aftermath of the recent crisis, in particular capital requirements and macro prudential regulations and suggests that they are in fact not new regulatory provisions, but have been employed for some time with little succeeds and are thus not likely to shield developing countries for the financial instability caused by the failure of governance in developed country markets.
\end{abstract}

Keywords: financial management, economic system, economic crisis, monetary policy, financial institution, regulation, governance 


\section{The Nature of Financial Institutions}

The methods of financial governance depend on how financial services impact the pursuit of government's policy objectives. The traditional approach considers finance and financial services as equivalent to any other good or service provided in the economy; provision is thus subject to the operation of market forces and governance involves augmenting the operation and efficiency of those forces. Indeed, one of the major post-war criticisms of one of the most successful examples of financial governance, the New Deal Glass-Steagall Act, was that it created a monopoly for commercial banks in the provision of insured bank deposits which provided them zero cost funding. Like any monopoly these conditions were considered as market imperfections and thus considered as inefficient and a wasteful misallocation of resources. The wave of deregulation and liberalisation of US financial markets that occurred in the 1980s was based on this argument. In the context of the run up to the recent financial crisis this traditional approach was represented by the Chairman of the Board of Governors of the Federal Reserve System Alan Greenspan who based his approach to governance of the financial system on the idea that market forces limit leverage and risk: "private regulation generally has proved far better at constraining excessive risk-taking than has government regulation." (GREENSPAN, 2008) An alternative approach, based on the contributions of Keynes, Schumpeter, Minsky and other analysts of monetary cycles argue that financial institutions and financial services are inherently different from produced real goods and services and the standard conditions for the existence of market supply and demand are not satisfied and are thus inapplicable. In particular, this relates to the absence of any constraints on the degree of leverage and financial innovation that is the basis of the creation of money, liquidity and near-money substitutes, requiring active governance of the process by government regulatory authorities.

It is important to note that representatives of the diverse approaches to governance both as Greenspan and Hyman Minsky agree that the driving force behind the instability of the financial system; they diverge on the most appropriate governance mechanism. For Greenspan "The very nature of finance is that it cannot be profitable unless it is significantly leveraged... and as long as there is debt, there can be failure and contagion." (GREENSPAN, 2013) This assessment is virtually identical to Minsky's view: "Banks are profit maximizing organizations. The return on owners' equity is $P / B=(P / A)(A / B)$ where $P$ is profits, $B$ is the book value of owners' equity, and $A$ is assets. Given this profit identity, bank management endeavors to increase profits per dollar of assets and assets per dollar of equity." (MINSKY, 1977: 17) But, Minsky adds an additional factor, that innovation is an integral part of the creation of leverage: "During periods of banking and financial innovation, the supply schedule 
of credit to business is virtually infinitely elastic. The availability of financing leads to increases in 1) capital asset prices relative to income, 2) the demand for investment goods, and 3) investment activity that is financed. The period in which a virtually infinitely elastic supply of credit exists is transitory, however, for the ever increasing amount of investment that is financed will lead to first an inflation in prices relative to wages and then to a wage inflation."(MINSKY, 1977: 17-9) One of the most important innovations in the recent period has been the use of derivatives: And also here Greenspan's assessment is based on the application of market controls: The reason that growth has continued despite adversity, or perhaps because of it, is that these new financial instruments are an increasingly important vehicle for unbundling risks. These instruments enhance the ability to differentiate risk and allocate it to those investors most able and willing to take it. This unbundling improves the ability of the market to engender a set of product and asset prices far more calibrated to the value preferences of consumers than was possible before derivative markets were developed. The product and asset price signals enable entrepreneurs to finely allocate real capital facilities to produce those goods and services most valued by consumers, a process that has undoubtedly improved national productivity growth and standards of living. (GREENSPAN, 1999)

Thus both consider leverage (the excess of the institution's liabilities over owners' equity) as endemic and essential to the operation of the financial system. And both would have accepted Minsky's citation of Henry Simons: "Banking is a pervasive phenomenon, not something to be dealt with merely by legislation directed at what we call banks" The only difference is in how to reign in the operation of competitive innovation and the profit motive with the fact that leverage, which determined the supply of finance, is not subject to equilibration by any market forces. For Minsky "a fundamental flaw exists in an economy with capitalist financial institutions, for no matter how ingenious and perceptive Central Bankers may be, the speculative and innovative elements of capitalism will eventually lead to financial usages and relations that are conducive to instability."

Indeed, Greenspan also appeared to share this view for in the aftermath of the recent financial crisis he recognized the error of his belief in the limits on the creation of liquidity by means of leverage was subject to market forces: "I made a mistake in presuming that the self-interest of organizations, specifically banks, is such that they were best capable of protecting shareholders and equity in the firms." "Those of us who have looked to the self-interest of lending institutions to protect shareholders' equity, myself included, are in a state of shocked disbelief." "I've found a flaw. I don't know how significant or permanent it is. But I've been very distressed by that fact." (GREENSPAN, 2008) 
As the greatest financial crisis since the Depression of 2007-8 morphed into the Great Recession of 2009-14 there appeared to be a consensus that the market was not capable of governing finance without a more rigorous set of regulations and supervision. This general agreement led to a series of Reports and measures proposing increased governance of financial institutions and in particular of banks issuing insured deposits serving as means of payment. In the United States the Dodd-Frank Act was introduced, in the United Kingdom the Vickers Report proposed ring-fencing commercial banking deposit taking activities, and the European Union Likannen Report, and the introduction of stronger central regulations in the form of the Single Rule book. Even international organisations were involved, in particular with the upgrading of the Financial Stability Forum, created in the aftermath of the Asian Crisis, to a Financial Stability Board, given broad powers by the Washington meeting of Heads of State and Government after the outbreak of the financial crisis in 2008.

Unfortunately, instead of focusing on the most appropriate measures to ensure stability of the economic system as a whole through enhanced and improved financial governance, much of the newly introduced governance legislation sought to respond to criticism that central banks and government agencies had allowed creditors to escape losses, bankers to escape prosecution and their insolvent financial institutions to be bailed out with government funding, rather than supporting the debtors, in the US households by writing down their underwater mortgages, and the Southern tier countries of the Euro zone by writing down government debts. Indeed, one of the major causes of the transformation of the financial crisis into generalized economic recession and growing unemployment was the asymmetric response to the crisis, supporting creditors and the value of impaired assets and imposing adjustment on the debtors without pursuing policies that eased their ability to service their debts.

Aside from a number of institutional provisions, such as the creation of numerous committees on the national and international level to monitor financial institution behavior and to warn of impending financial crises and to propose ex ante measures to avoid them, the main remedial measures have been: ${ }^{1}$

Regulations (in the US known as the Volcker rule) that restrict proprietary trading by regulated and insured subsidiaries of financial institutions. The intention is to reduce the subsidy to risk-taking created by provision of deposit insurance to the liabilities of these institutions.

\footnotetext{
${ }^{1}$ The measures have been proposed by a number of different bodies such as the Financial Stability Board, the Bank for International Settlements, national governments' regulatory agencies and in the case of the European Union the creation of a Single Rule Book which consolidates many of these measures under the authority of the European Central Bank (cf. TONVERONACHI, 2015)
} 
Rapid Resolution Authority, including "Living Wills" which provide a procedure for the bankruptcy of very large financial institutions according to a detailed plan of distribution of assets and liabilities (the living wills) to act as a substitute for government rescue and again to reduce the implicit subsidy to banks that are believed to be rescued in the event of insolvency.

Higher Capital ratios -- Enhanced Owners' Equity: to cover anticipated losses from excessive risk-taking and to avoid crisis. The idea is that bailouts can be avoided if PSI requires equity owners to absorb the losses from excessively risky behavior. Unfortunately this approach ignores the fact that a single case of equity write-down would be contagious to other institutions. Finally, the risk weighted capital asset ratios are supplemented with aggregate capital and liquidity ratios, with special supplements for large banks and rebasing the ratios on a more limited definition of capital limited to owners' equity or what is the context is called "loss absorbing" capital.

Liquidity buffers -- to ensure a higher share of liquid assets in portfolios to provide a first line of defence in meeting losses from excessive risk taking so that financial institutions can maintain funding by drawing on liquid marketable assets to meet a shortfall in funding in the case of portfolio losses and thus prevent a liquidity crisis from degrading into insolvency.

Stress Tests -- virtually all bank regulators have initiated stress tests to gauge the loss absorbing capacity of capital positions in event of an extreme crisis. The standard is that the bank should have enough capital to absorb losses in a severely adverse economic environment and continue to lend to households and businesses However, these event scenarios still do not assess the impact of interbank exposures and assume that existing balance sheet structure remains unchanged in response to a series of losses, yet it is precisely these responses to crisis that may well be the major contributing factor in crisis! As a result, these measures technically remain under the rubric of microprudential regulation. Many regulators also limit permission to grant dividends and increases in executive compensation to the successful completion of the stress tests.

It is perhaps unnecessary to note that the reliance on capital as a regulatory device depends on control of principals on their agents and the fact that this does not in general exist in Financial Markets as admitted by Alan Greenspan in "shocked disbelief": "The Agents (Management of Financial Institutions) have no self-interest to protect Principals' (the shareholders') equity".

Amongst the myriad of particular measures that have been proposed by governments in the countries worst impacted by the financial crisis (the DoddFrank Act comprises over 800 pages and calls for some 400 additional rules to be 
written by various financial agencies, plus a series of studies and reports to be produced) the major innovations in financial governance introduced in response to the crisis are in the importance given to macroprudental regulation and enhanced capital ratios and liquidity buffers. The rest of this paper will provide an analysis of the effectiveness of these new approaches to financial governance as a means of enhancing the financial system stability and assess how they have improved the operation of the financial system.

\section{The New Role for Bank Capital ${ }^{2}$}

Concerns about bank capital ratios first arose in a special committee in the Bank for International Settlements to deal with risks in the clearing of international transactions following the failure of Herstatt Bank in 1974. It produced two Concordats that sought to allocate regulatory responsibility for banks operating internationally to their home regulatory agency and to provide for global consolidated balance sheet reporting. The rapid rise in international lending produced by the petroleum crisis later in the decade led the Committee to increase focus on the sharp decline in bank capital, and its inadequacy to meet Latin American defaults on syndicated lending. As will be discussed below, it was these concerns that led the Cooke Committee (which was to become the Basle Committee on Bank Supervision) to formulate what it called "macroprudential" regulations. (CLEMENT, 2010)

In essence the Concordat was an international supervisory agreement designed to provide a substitute for an absent international lender of last resort, or better, for the assignment of international lender of last resort responsibility for banks operating internationally. It was the failure of the Concordats to achieve this latter objective that led to the push for international capital adequacy as a second-best substitute. It was given further impetus as a means of providing a "level playing field" for international banks when Japanese banks, with virtually non-existent equity capital, started to dominate the London Eurodollar markets to the detriment of US and European banks. The first formal proposal for capital ratios to be applied to banks operating internationally (Basle I), was issued by the BCBS in 1988 for formal approval by national regulatory bodies.

Minimum capital adequacy regulations in various forms in various jurisdictions had existed throughout US banking history, and after the creation of the Federal Reserve were frequently proposed, but never introduced in the post-war period. This was largely due to the dual regulatory structure of National and state chartered banking that characterized the US financial system. It was the rapid expansion of

\footnotetext{
${ }^{2}$ A more extensive discussion of the Basle proposals is in Kregel (2006)
} 
bank lending in the aftermath of the sharp rise in oil prices and US inflation that led Paul Volcker in December 1981 to introduce the first numerical minimum capital adequacy ratio of 5 per cent for primary and 5.5 per cent for total capital. ${ }^{3}$

The motive behind Volcker's decision was the failure of money supply control to reduce bank lending (or inflation as had been promised by monetarist economists). Banks simply maintained lending margins by raising interest rates in step with inflation and continued to expand lending, irrespective of the level of policy rates, and without any need to raise bank equity. Thus, Wall Street analysts such as Henry Kaufman suggested that a more effective policy of regulatory capital ratios would force banks to raise equity to support their increased lending. If capital markets recognized the increased riskiness of the banks' loan portfolios they would reduce bank multiples pushing up the cost of capital to the point at which banks would no longer find it profitable to lend. The imposition of capital standards at that time was also in line with the trend toward deregulation and increasing the role of the market in determining interest rates.

For comparison with the current approach to capital ratios, it is important to recognize that capital adequacy ratios were initially viewed as a monetary policy measure, not as a regulatory measure to ensure bank solvency. The point had already been noted by Cooke (1949: 77) who concluded that "a required capital ratio may prove advantageous as a general credit control device."

Indeed, there seems to have been very little historical support for bank capital as a bulwark for bank solvency. A study of the bank statements of failed and successful Florida State Banks in the period 1922-1928 (the first Florida banking crisis that preceded the 1929 collapse) found that "A comparison of the statements of the groups of failed and successful banks discloses the interesting fact that ... the net worth of the failed banks was a noticeably larger percentage of total liabilities than was the net worth of the successful banks. (12.9\% and $10.4 \%$ respectively)." The basic reason was "the larger and more rapid increase of the resources of the failed banks during the boom created problems of wisely investing the added funds." Rather than increasing their cash holdings, the banks rushed to invest the funds in increasingly doubtful real estate projects. The rapid increase in assets was rewarded by the stock market as an indication of increased future earnings, instead of representing an increase in the volatility of earnings due to the possible

\footnotetext{
${ }^{3}$ However, the seventeen largest banks operating in international markets were exempt. The official explanation was that they had access to superior liquidity and confidence and thus required less capital -however, as would become evident the following year, the real reason was that they were unable to meet the new minimum requirements, even before the Mexican default. In April 1985 the ratios were increased to 5.5 and 6.0 per cent, despite the fact that in the intervening period Continental Illinois Bank had collapsed with a 5.8 per cent ratio.
} 
overinvestment in real estate in the area (much of which was still under swamp water). The capital market clearly provided no limit on the ability of these banks to expand their doubtful lending practices. A very similar episode took place in the 1980s as savings and loan institutions attempted to grow their way out of the difficulties created by the deregulation of the US financial system.

In theory, the imposition of capital ratios was to increase solvency by giving shareholders incentives to constrain bank management expansion into excessively risky lending to raise returns. If capital requirements have had scarce success as a constraint on bank lending, it is unlikely that they should have a positive influence on bank solvency. The already cited report of the 1920s Florida real estate crisis presented the traditional view of the role of bank capital noting that "net worth items not only disclose the volume of funds furnished the bank by stockholders, but also measure the amount of shrinkage and loss that can take place among the assets before any loss can fall upon the depositors." However, it goes on to note "The fact that the net worth was a greater percentage of total liabilities of the failed banks than of the successful, apparently disclosed a sounder and more favourable condition, for it indicated that the failed banks had a relatively larger amount of owners' investment with which to absorb shrinkages and losses among the assets before the losses could fall upon the depositors." Yet this did not turn out to be the case. And this is not a view that was limited to the historical experience of the 1920s.

Cooke $(1949,75)$ noted that "data compiled from the annual reports of the Comptroller of the Currency show that, although their surplus and reserves had been wiped out, national banks which failed during the twenty-five year period from 1920 to 1944 generally had only slightly lower capital-deposit ratios [from 10.6 per cent to 32.3 per cent] at the date of failure than active ones." She also notes that capital ratios shot up in 1934, as depositors withdrew funds the capital ratio would automatically rise.

A study published in 1995 (cited in MATTEN, 2000:34) comparing a retrospective assessment of American banks' capital adequacy measured under the original Basel Accord with the actual soundness of banks measured by the classification by US bank supervisors based on their "CAMEL" scores and actual insolvencies for the period between 1984-1989 showed that more than half of the failed banks in this period and about three quarters of the banks that were rated high risk problems by their supervisors would have been classified as either adequately or well capitalized under the risk-based capital regime introduced by the Basel Accord.

George Vojta states that "Levels of capitalization appear to have had no direct causal relationship to the incidence of bank failure." Nor is there evidence to suggest that increasing capital ratios provides increased protection against bank failures. 
And there seems to be a number of good reasons for this. The first is the precise role to be played by capital in providing stability. Bankers have generally tended to argue that capital is not required to face general losses from their activities. These losses are to be met from current income. For example, a Citibank study covering the period 1962-72 showed that "in no year did after tax loan charge-offs exceed 13.1 per cent of after tax earnings, and that on average charge-offs in that period were 6 per cent of annual earnings. ... Average chargeoffs as a percentage of the loan loss reserve were 3.5 per cent... After tax loan losses averaged less than 0.5 per cent of total capital accounts." Thus, on average bank losses will be covered through income flows, not met by capital. Indeed, most bankers would argue that capital is meant to protect the bank from abnormal conditions. However, Lucille Mayne (1972) notes "that it is not possible to devise a generally acceptable measure of capital adequacy since the essential function of capital is to serve as a defense against the occurrence of unpredictable events."

Vojta goes further and suggests that "[t]he capital account of a bank is not adequate to maintain solvency in the event of a major liquidity crisis... Effective defense against ultimate crisis comes from lenders of last resort" that is from the central bank. Finally, Vojta notes that "This does not mean that the government is expected to bail out mismanaged institutions; but neither should financial institutions be expected to be so overcapitalized as to bail out government's mismanagement of the economy. As a matter of fact and practicality, the economic disaster case should be excluded as a relevant scenario for capital adequacy purposes." The clear position of the financial industry is that capital is not an efficient means of providing a defence against abnormal conditions such as a systemic crisis - this is the role of lender of last resort, and is not the relevant factor in dealing with normal losses these are best dealt with through provisioning out of income and chargeoffs. ${ }^{4}$

But, the current justification for capital ratios has nothing to do with their ability to constrain risky lending activity or to reinforce principals' monitoring of their agents. It is agnostic about the business model and operating mechanism of financial institutions and simply proposes to set bank capital at a level sufficiently large to cover any conceivable losses without incurring technical insolvency. It is thus also independent of any attempt to mitigate risky behavior or to provide an early warning market mechanism for impending instability.

However, it does rest on the ability to envisage the worst case scenario of systemic losses, supported by the stress tests. And not only is there no theoretical

\footnotetext{
${ }^{4}$ Vojta, op cit., p. 179. He gives as example the 1969 credit crunch in which "No level of capital would have been adequate to permit affected institutions to withstand general stress of this magnitude." And "It was only the intervention of the Federal Reserve that avoided collapse of the entire financial system." p. 173, note 10.
} 
or practical way of measuring this magnitude (this is what value at risk (VAR) was supposed to provide) without being able to predict the innovations that the imposition of capital requirements will generate in financing practices as financial institutions compete for profit.

It has been argued that irrespective of efficiency, the imposition of higher capital ratios is a virtually costless means of reducing financial instability. In contrast to the arguments used in the 1970s when it was considered an instrument of monetary policy it is now argued, on the basis of the Modigliani-Miller theorem, that higher capital ratios will have no impact on bank lending rates (see ADMATI and HelLWELL, 2013). The argument is that in perfect capital markets absent tax distortions, the composition of bank capital between equity and debt should have no impact on the cost of capital. Aside from the fact that the assumptions required for the validity of this result are never met in real financial markets, and there is no statistical evidence to support the claim (see CLINE, 2015), more important it that the argument is based on a static equilibrium result applied to a dynamic disequilibrium adjustment process. In a crisis additional capital would have to be raised in distressed market conditions, and has J. Dimon (2015) has pointed out, in the last crisis "Banks continued to lend freely because effectively they are the "lender of last resort" to their clients as the Federal Reserve is to the banks". But in the event of a future crisis because of the higher capital requirements JPMChase would be unwilling to accept deposit transfers from weaker banks because of it would require higher capital since additional deposits would incur higher capital charges. In the next crisis "It will be harder for banks either as lenders of last resort or as market-makers to "stand against the tide."

The result of such procyclical behavior by stronger banks facing additional capital requirements would mean an overall decline in lending and an overall rise in capital costs and borrowing rates in response to crisis. The result of a static equilibrium adjustment process cannot be used to explain the dynamic adjustment of the system to distressed conditions. ${ }^{5}$

Finally, there is no method to adequately measure bank equity as "loss absorbing" capacity. First because capital is an accounting concept and bears no relation to the realizable value of bank assets financed with bank equity. And as both Greenspan and Minsky noted in quotations above, the viability of the financial sector depends on the existence of leverage to produce bank earnings. As noted by Vojta above, and shared by Minsky, the most important element in a financial institution's stability is the ability of its debtors to generate the cash flows to service their debt, and second

${ }^{5}$ He also notes the negative impact on dealer markets which depend on leverage to fund inventory: "Market depth ... a precursor of liquidity ... of 10 -year Treasuries ... today is $\$ 125$ million, down from $\$ 500$ million at its peak in 2007." 
to be able to generate sufficient income to meet the market return to capital for it is the search for higher incomes that drives the innovation in financial practices which is at the basis of financial instability and the potential for systemic risk. It is in this sense that bank stability is a question of the operation of the broader macro economy and that has led to the interest in macroprudential regulations.

\section{MacroPrudential Regulation}

As noted above, "macroprudential" regulation is not really a new concept, having been implicitly proposed by Minsky in his early work in the 1960s and 1970s and then independently developed by the Cooke Committee of the Bank for International Settlements, largely under the influence of the work of its then Economic Adviser (subsequently Managing Director), Alexandre Lamfalussy, as he attempted to suggest measures to forestall what he considered to be the forthcoming Latin American debt crisis.

Minsky had early criticized the traditional "micro" approach to bank regulation, in which "The instability of banks and other financial institutions is usually described in term of runs and defaults at particular institutions without a clear explanation of why such strong assets substitution quite suddenly becomes the rule of the day. When conceived in terms of bank runs and defaults, a particular bank fails because of its own, idiosyncratic attributes. Its management has been incompetent or committed fraud. Such a failure may have repercussions on other banking institutions, in that for a time financial markets fail to work normally. This creates transitory refinancing problems for otherwise solvent banks, ... idiosyncratic failures can trigger an epidemic of bank failures, imparting an adverse "depressioncreating" shock to the economy." (H.P. MINSKY and CLAUDIA CAMPBELL, 1987: 254-5). Thus "microprudential" regulation looks ideally at the structure and comportment of an individual bank, rather than its relations with the rest of the financial system or the overall macroeconomic environment.

In the US, there was a shift away from this approach after the crisis of the savings and loan banks in the 1980s towards a more "risk"-based approach, although the then Chairman of the Federal Deposit Insurance Corporation (FDIC) claimed that the changes "do not reflect a fundamental change in the FDIC's traditional approach to risk assessment". She nonetheless noted that examinations were "working to "bridge the gap" that currently separates the "macro" perspective of economics and market trends from the "micro" perspective of bank examinations in ways that will translate data into guidance that examiners can use in assessing and monitoring risks in institutions with differing levels and types of risk exposure. ... The result will be a 
more effective and accurate assessment of an institution's ability to manage its risks within a structured framework, which will enhance safety and soundness." (HELfER, 1996) Despite the clear recognition of impact of macro conditions on micro prudential regulation the approach still placed the emphasis on the examination of the individual institution, rather than on systemic impacts on the entire financial system.

AS noted above, the BIS and its Economic Adviser were stimulated by the sharp rise in bank lending relative to bank capital to push for higher capital standards, but also recognized that they would not be sufficient given the system nature of the forces that were propelling the increased international lending. They thus noted that "Prudential measures are primarily concerned with sound banking practice and the protection of depositors at the level of the individual bank. Much work has been done in this area - which could be described as the 'micro-prudential' aspect of banking supervision. [...] However, this micro-prudential aspect may need to be matched by prudential considerations with a wider perspective. This 'macroprudential' approach considers problems that bear upon the market as a whole as distinct from an individual bank, and which may not be obvious at the microprudential level." ("The use of prudential measures in the international banking markets", 24 October 1979, pp 1-2, in BISA 7.18(15) - Papers Lamfalussy, LAM25/ F67. quoted in Clement, op. cit., p. 61).

According to Ivo Maes (2010), the broad Bank for International Settlements "approach to financial stability, "marrying" the micro and macro-prudential dimensions of financial stability with its emphasis on the macro-prudential dimension, first came to the fore in the Cross Report on innovations in international banking. ... this was the first published official document that used the term "macro-prudential" The Cross Report defined the macro-prudential domain as "the safety and soundness of the broad financial system and payments mechanism" (BIS, 1986, p. 2). ... it focuses on the financial system as a whole, paying attention to the macroeconomic dimension of financial crises. It treats aggregate risk in the financial system as dependent on the collective behaviour of the financial institutions (which contrasts with the microprudential view, where financial institutions are regarded as having no influence on the global situation).

Thus while both Minsky and Lamfalussy provide a similar critique of traditional micro regulation and suggest the importance of formulating regulations that deal with the systemic nature of financial crisis, and in particular, the role of financial innovations as an integral part of the systemic factors that should be covered in macroprudential regulation there is a basic difference in their approach. And that difference lies in the fact that Minsky argued that it was impossible to formulate a coherent approach to macro regulation without and underlying theory of systemic 
crisis. If micro regulation was grounded in an explanation of the behavior of individual banks, macro regulation would require an explanation of the behaviour of the entire banking and financial system. It was the search for this groundwork theory that led to Minsky's Financial Instability Hypothesis, developing Keynes's "foundations of an investment theory of business cycles and a financial theory of investment in a capitalist economy" (MINSKY, 1994:2) to provide the explanation of the cyclical behavior and the systemic interactions that could provide the basis for the formulation of "macroprudential" regulation.

The current approach to macro prudential regulation still lacks this fundamental theoretical grounding. For example, according to Haldane (2014:2) "Since the crisis, financial regulation has become explicitly macro-prudential. This is an expression much-used, but generally little-understood. In a nutshell, it means that policymakers have begun using prudential means to meet macro-economic ends. Those macro-economic ends include tempering swings in credit and leverage the classic credit cycle. Or, put differently, curbing the credit cycle appears to be an important ingredient of broadly-based macro-economic stability. For Persaud (2009) "Prudential Regulations for the Macro Economy" can be characterized as "A growing consensus around three ideas: Capital requirements need a countercyclical element to "dampen rather than amplify the financial and economic cycle" by "requiring buffers of resources to be built up in good times." ... Greater emphasis on rules rather than supervisory discretion to counterbalance the political pressures on supervisors. ... rules should include leverage limits liquidity buffers."

The modern approach thus falls short of Minsky's view that any macro prudential regulation would require " $A$ more complete description of the instability of an 'economy with banking'." Such an approach needs to look behind the runs and analyze the structure of balance sheets, payment commitments and position-making activities. Position-making for a bank consists of the transactions undertaken to bring the cash position to the level required by regulation or bank management. In the position-making view, bank failures do not arise simply because of incompetent or corrupt management. They occur mainly because of the interdependence of payment commitments and position-making transactions across institutions and units." (MINSKY and CAMPBELL, 1987: 255) Minsky thus went on to recommend and to make formal proposals for a Cash flow Examinations system to Support Macro Prudential Regulations: "Examination and analysis balance sheets based on the view that liquidity is not an innate attribute of an asset but rather that liquidity is a time related characteristic of an ongoing, continuing economic financial institution." Basic to the idea of liquidity as an attribute of an institution is the ability of the unit to fulfill its payment commitments. Any statement about a unit's liquidity, therefore 
depends upon estimating how its normal activities will generate both cash and payments, as well as the conditions under which its assets (including its ability to borrow as an "honorary" asset) can be transformed into cash. . . . Any statement about the liquidity of an institution depends upon assumptions about the behavior of the economy and financial markets. As the assumptions are changed, the estimate of the liquidity of the institutions will vary.

But, in Minsky's view the error in Macroprudential regulation is the same as that noted above in applying enhanced capital ratios, it is based on an essential static supply and demand analysis when not only is supply and demand in appropriate, it is the static analysis which is an even greater cause of concern.

\section{Dynamic Macro Prudential Regulation ${ }^{6}$}

But Minsky's "new" approach was not only to recognize the cyclical nature of the interactions generated by financing relations within the economic system, it took a much broader approach to regulation: "The supervisory and regulating structure for banking and finance that is in place not only reflects institutional features of the economy stretching back over at least 150 years, it also reflects the understanding, i.e. the economic theory, of how our type of economy works that ruled at the time when the bits and pieces of this structure was first put in place." (Minsky, 1994:6) Indeed, this was one of the advantages of Minsky's proposed cash-flow approach: "The perspective underlying the suggestions was of a dynamic, evolving set of financial institutions and relations. All too often it seems as if the Federal Reserve authorities have been surprised by changes in financial practices. One aim in the design of the examination system was to establish a regular reporting procedure which would force the authorities to be aware of institutional changes that were ongoing, and which furthermore forced the authorities to inquire into how the ongoing developments can be expected to affect the stability of the financial system." In a subsequent note Minsky gave as example: "One byproduct of the cash flow examination procedure will be more precise knowledge of the relations between the examined institutions and fringe banks. Such a clarification will enable the Federal Reserve to better know what is emerging in financial relations and to be better prepared for contingencies that might dominate as the determinants of its behavior." (Minsky, 1975:2)

That is, regulation must be institution and theory specific, which is why it must be reassessed frequently in relation to the changes taking place in the financial system. Examination was thus intended to force the central bankers to become aware of

6 This section draws on Kregel (2014) 
ongoing institutional and operational changes in the financial system, something that was clearly lacking in the Fed's analysis of the recent crisis which has now been revealed to have ignored the mechanics of securitization of subprime mortgages and the role of credit default swaps in the interrelationships between banks and other (fringe or shadow) institutions operating in these markets.

One of the advantages of the use of Minsky's approach to regulation based on the $\mathrm{FIH}$ as the basis for macro prudential regulations is thus that it "explains why regulatory structures eventually become obsolete or perverse. The normal, profitseeking activities of agents lead to innovation in order to create new sources of profits; innovation can be in products, process or finance. The search for profits also drives agnates to avoid, evade and adapt to the structure of regulation and intervention put in place to constrain incoherence. In time this undermines the effectiveness of a regime of intervention that "stabilizes the unstable system". Therefore if regulation is to remain effective, it must be reassessed frequently and made consistent with evolving market and financial structures." (MINSKY and CAMPBELL, 1988: 6) Minsky stressed the point that "As the monetary system, the financial system and the economy are always in the process of adapting to changing circumstances, the quest to get money and finance right may be a never ending struggle." because what is an appropriate structure at one time is not appropriate at another. Throughout our history the reaction to some 'unpleasant events' in banking or finance has been to reform the structure of banking and finance, as well as the structure of government chartering, regulation and supervision of financial institutions. Our predecessors were not fools: ... they knew the institutions of their time well enough so that when legislation changes institution, the new structure succeeded in correcting the malfunctioning, for at least the time being. Such a new structure of payments and financing was apt enough, so that a 'better' performance of the economy followed. However the perennial quest for the profits that successful innovators earn, energizes entrepreneurs. New financial and banning institutions and new financing patterns for business, households and government units emerge and their users prosper. Over time the initially apt pattern of regulation and supervision becomes increasingly inept: the inherited structure of regulation and the supervision first becomes not quite right and later becomes perverse. A cumulative effect of the institutional and usage changes that occur is that the institutions which are supped to contain the endogenous disequilibrating forces of our economy lose much of their power to do so." (MINSKY, 1994: 4-5)

As an example he noted "The shift in position-making from trading in liquid assets in the 1960s to transactions in liabilities in the 1970s" and the "decrease in the margins of safety used to cushion fluctuations in cash flows. As a result, payment 
commitments have become more closely coordinated with payment receipts so that small changes in conditions can cause a large increase for units (households and businesses who are indebted to banks and banks that are indebted to depositors) to acquire cash by selling assets that may have thin markets." (MINSKY and CAMPBELL, 1987: 255) This leads to a need to sell assets to acquire liquidity which causes a decline in asset prices and a "process that leads to a deep depression". Minsky thus argued that "The problems today are the result of competition for profits that has transformed an initially robust financial structure into a fragile system and in so doing made obsolete the structure of deposit insurance established 50 years ago." (MINSKY and CAMPBELL, 1988:7)

From this point of view the greatest error committed in the run up to the recent crisis was to allow a major change in the institutional structure of the financial system in the 1999 Financial Services Modernisation Act without any accompanying changes in the regulatory or supervisory structures.

The conclusion, which is just as relevant today, is that "The introduction, in today's environment of ... capital requirements and greater public disclosure of problem institutions ... would make it more, not less, likely that insurance payoffs will be required. In addition, these reforms would increase system instability." (Ibid.: 253)

\section{What Has Changed?}

This paper has suggested that the two major changes that buttress the increased role of financial governance in the aftermath of the financial crisis and Great Recession are not really new. Both increased capital ratios and macroprudential regulation date back to the financial crisis of the 1970s and have been in continuous use since then. They do not seem to have been prophylactic in preventing the increasing number and virulence of financial crises since that time. The analysis of the operation of these measures suggests that there is ample reason to believe that they are not particular efficient in providing governance of the financial system capable of preventing financial instability. As noted, building on Minsky's work, one of the basic difficulties with these measures is that they are not grounded in a solid theoretical explanation of the way the economy with a financial system generates crisis.

One of the most important elements in the failure of these measures is the belief that they are supported by a governance mechanism based on market forces. This was the response to the crisis in the 1930s, as well as the crisis of the 1980s which produced the proposals for capital ratios and macroprudential regulations. The response to the current crisis is no different as can be seen from a recent statement from Alan Greenspan: "An important collateral pay-off for higher 
equity in the years ahead could be a significant reduction in bank supervision and regulation. Lawmakers and regulators, need to be far less concerned about the quality of the banks' loan and equity portfolios since any losses would be absorbed by shareholders, not taxpayers. This would enable the Dodd-Frank Act on financial regulation of 2010 to be shelved, ending its potential to distort markets - a potential seen in the recent decline in market liquidity and flexibility." Basically the position is that sufficiently high capital ratios will allow the operation of market forces as the only governance mechanism. In this position, we can conclude that nothing has changed in the dominant approach that the most effective financial governance is through the market.

\section{Addendum: An Alternative for Brazil?}

Is there an alternative? Real changes in financial governance requires a change in financial structure in order to control leverage. This would involve prohibiting financial institutions from offering means of payment through transferable deposit account, and to have them operated by a government agency, much like the postal savings banks that at one time existed in most countries. This would eliminate the profit driven innovation in the creation of leverage and liquidity in the system. Further, Minsky suggested that "it is worth investigating whether a permanent government Investment bank, such as the Reconstruction Finance Corporation, is a desirable feature for an economy where solvency crises are likely to occur" (MINSKY, 1994: 11) This would mean that the degree of liquidity in the system would be driven by the government's fiscal policy.

This is a real change that could be implemented quite easily in Brazil since it is one of the few countries that has retained a highly successful government development bank. It is perhaps ironic that the bank is currently under threat because it has recently received financing from the Federal budget when this is a major opportunity for increased financial governance and an element of stability in the financial system since it is the government that is levered, not the Bank. National governments can never default on debt issued in their own currency.

Part of the criticism is based on the idea that it provides a subsidy to the Bank's clients and distorts competition with private financial institutions since the Bank lends at an interest rate that is lower than the rate at which the government itself borrows to fund the Bank. But this is first, a problem of monetary policy and governance of the Central Bank. And secondly it overlooks the subsidies provided to the private banking system whose investment portfolio is dominated by holdings of government debt which allows them to earn returns on equity in excess of 20 per 
cent, double the standard in the rest of the world. The reason is, that in addition to the high interest rates due to monetary policy, the government offers its debt with inflation, interest rate and exchange rate guarantees. That is, the debt includes options that cover all the risks of holding the debt, which is already in essence credit risk free, since the government cannot default on the debt. The value of these implicit "options" also represent subsidies to the private banks and a major contribution to the costs of financial stability in Brazil. Any clear comparison of subsidies to the development bank and the private banks must take these subsidies to the private sector into account.

\section{References}

AdMATI, A and M HellWig (2013), The Bankers' New Clothes: What's Wrong with Banking and What to Do about It, Princeton University Press.

ANDREWS, Edmund L. (2008) "Greenspan Concedes Error on Regulation," The New York Times, October 23, B1 http://www.nytimes.com/2008/10/24/business/ economy/24panel.html?_r=0

CLEMENT, Piet (2010) "The term "macroprudential": origins and evolution," BIS Quarterly Review, March, 59-67

CLINE, William R. (2015) "Testing the Modigliani-Miller Theorem of Capital Structure Irrelevance for Banks" Petersen Institute for International Economics, Working Paper WP15-8 April

COOKE, Helen Mellon (1949) "Significance of Bank Capital Ratios," Journal of Political Economy, Vol. 57, No. 1, February

Bank for International Settlements (1979) "The use of prudential measures in the international banking markets", 24 October in BISA 7.18(15) - Papers Lamfalussy, LAM25/F67.

(1986) "Recent innovations in international banking" (Cross Report), April 1986, ISBN 92-9131-050-6

DIMON, Jamie (2015) "Run on the market: A thought exercise on what might be different in the next crisis," in Annual Report for 2014 of JPMorgan Chase Bank: Solid Strategy and Future Outlook http://www.jpmorganchase.com/corporate/ annual-report/2014/ar-solid-strategy.htm

Greenspan, Alan (1999) "Financial derivatives," Remarks by Chairman Alan Greenspan

Before the Futures Industry Association, Boca Raton, Florida, March 19, 1999 www.federalreserve.gov/boarddocs/speeches/1999/19990319.htm

(2013) "An interview with Alan Greenspan" By Gillian Tett, Financial Times, October 25

(2015) "Higher capital is a less painful way to fix the banks" Financial Times, 18 August 2015, 11 (Italics added). 
(2008) statement of Alan Greenspan, House Hearing, 110 Congress, Second Session, The Financial Crisis And The Role Of Federal Regulators Before The Committee On Oversight And Government Reform, October 23, Serial No. 110-209 http://www.gpoaccess.gov/congress/index.html

Haldane, Andrew (2014) "Ambidexterity" Remarks Delivered at the American Economic Association Annual Meeting, Philadelphia on 3 January, published on 14 March 2014 http://www.bankofengland.co.uk/publications/Documents/ speeches/2014/speech713.pdf

Harwood Dolbeare and Merle O. BARND, (1931) "Forewarnings of Bank Failures," A Comparative Study of the Statements of Certain Failed and Successful Florida State Banks, 1922-1928" Bureau of Economic and Business Research, University of Florida, June

HeLfER, Ricki (1996) “Oral Statement by Ricki Helfer, Chairman, Federal Deposit Insurance Corporation before the Committee on Banking and Financial Services U.S. House of Representatives, March 13, 1996. http://www.fdic.gov/news/news/ speeches/archives/1996/sp13mar96.html

Kregel, Jan (2006) "O Novo Acordo de Basiléeia Pode Ser Ben-Sucedido naquilo em que o Acordo Original fracassou? In Regulação Bancária e Dinâmica Financeira, ed. Ana Rosa RIbeiro de Mendoça and Rogério P. de Andrade, Campinas: Unicamp, 2006 pp. 25-38.

(2014) "Minsky and Dynamic Macroprudential Regulation," Levy Economics Institute Public Policy Brief, no. 131

MAES, Ivo (2010) "Alexandre Lamfalussy and BIS efforts at preventing the LatinAmerican debt buildup in the second half of the 1970s" Paper prepared for the Aphes Conference, Lisbon, 15 October, Research Department, National Bank of Belgium

MATTEN, Chris (2000) Managing Bank Capital, New York: Wiley.

MAYNE, Lucille (1972) "Impact of Federal Bank Supervision on Bank Capital" BULLETIN, New York University Graduate School of Business Administration, Institute of Finance, nos. 85-6

Minsky, H. P. (1962) "Flow of Funds and Cash Flows." Paper 354. Hyman P. Minsky Archive, Levy Economics Institute of Bard College, Annandale-on-Hudson, N.Y

(1966). "Cash Flow Examination Procedures for Banks." Paper 134. MıNSKY Archive. (See additional files.)

(1967). "Suggestions for a Cash Flow Oriented Bank Examination." Paper 175. Minsky Archive.

(1972a). "Financial Instability Revisited: the Economics of Disaster." In Reappraisal of the Federal Reserve Discount Mechanism, vol. 3, 95-137. Washington, D.C.: Board of Governors of the Federal Reserve System.

(1972b). "A Perspective on 'Money.'” Paper 100. Minsky Archive.

(1975a). "Notes on: Suggestions for a Cash Flow Oriented Bank Examination." A document prepared for the Board of Governors of the Federal Reserve System in the summer of 1967. Paper 176. Minsky Archive. 
(1975b). "Suggestions for a Cash Flow-Oriented Bank Examination." In Proceedings of a Conference on Bank Structure and Competition. Chicago: Federal Reserve Bank of Chicago.

(1977). "Banking and a Fragile Financial Environment." Journal of Portfolio Management 3, no. 4 (summer).

and C. Campbell. (1987). "How to Get Off the Back of a Tiger, or, Do Initial Conditions Constrain Deposit Insurance Reform?" In Merging Commercial and Investment Banking-Risks, Benefits, Challenges: Proceedings, A Conference on Bank Structure and Competition, 252-66. Chicago: Federal Reserve Bank of Chicago.

and Campbell, Claudia (1988) "Getting off the Back of a Tiger: The Deposit Insurance Crisis in the United States", Minsky Archive. Paper 67

(1994a). "Financial Instability and the Decline (?) of Banking: Public Policy Implications." Paper 88. Minsky Archive.

(1994b). "Regulation and Supervision." Paper 443. Minsky Archive. (1995). "Reforming Banking in 1995: Repeal of the Glass Steagall Act, Some Basic Issues." Paper 59. Minsky Archive.

Persaud, A. 2009. "Macro-Prudential Regulation." ECMI Commentary 25, no. 4 (August).

Tonveronachi, M. (2015) "Post-crisis international regulatory standards and their inclusion in the European framework," in Rainer Kattel, Jan Kregel and Mario Tonveronachi, Financial Regulation in the EU, London: Routledge.

VOJTA, George (1976) "Bank Capital Adequacy", reprinted in Thomas Havrilesky and John Boorman, Current Perspectives in Banking: Operations, Management, and Regulation, Arlington Heights, Illinois: AHM Publishing Co.

Jan Kregel

Director of Research and Senior Scholar Levy Economics Institute of Bard College.

Contact: kregel@levy.org 